\title{
IN THE BALANCE: THE ART OF NORMAN ROCKWELL AND ALEX COLVILLE AS DISCOURSES ON THE CONSTITUTIONS OF THE UNITED STATES AND CANADA
}

\section{DAVID HOWES}

The author analyzes the nature of the Canadian and American constitutions through a series of analogies with the art of Alex Colville and Norman Rockwell as representatives of the culture and underlying mindsets of these nations. According to the author, the artists' perceptions of the world have been influenced by their respective nations' constitutions and the paintings of Colville and Rockwell thus express the values inherent in these constitutions. He contrasts the foundation of Canadian confederation, an alliance between two distinct linguistic and cultural groups, with the indivisible unity he ascribes to the American constitutional setting. The author concludes that by seeing the separation of figures in Colville's paintings and their fusion in Rockwell's, the viewer can grasp the essence of the countries the artists represent. The author further encourages constitutional law scholars to broaden their attentions to include legal interpretations of non-legal works, to develop "visual thinking" skills and a visionary attitude and to extend the field of constitutional studies to include a nation's "habits of the heart".
L'auteur analyse la nature des constitutions canadienne et américaine d travers une série d'analogie avec l'art d'Alex Colville et de Norman Rockwell, perçus comme les représentants de leur propre culture et de l'état d'esprit de leurs pays respectifs. Selon l'auteur, la façon dont l'artiste perçoit le monde serait influencée par la constitution de son pays. Ainsi, les tableaux de Colville et de Rockwell exprimeraient les valeurs inhérentes à ces constitutions. Il établit un contraste entre le fondement de la confédération canadienne l'alliance entre deux groupes linguistiques et culturels, et l'unité indivisible du cadre constitutionnel américain. L'auteur conclut qu'en examinant la façon dont les silhouettes se découpent chez Colville et se fondent chez Rockwell, il est possible de saisir l'essence des deux pays que les artistes représentent. L'auteur invite les spécialistes du droit constitutionnel à élargir le champ de leurs intérêts pour inclure l'interprétation juridique des oeuvres non juridiques, afin de développer un mode de pensée "visuelle", une attitude visionnaire, et d'étendre le domaine des études constitutionnelles pour y inclure les "habitudes de coeur" d' une nation.

\section{TABLE OF CONTENTS}

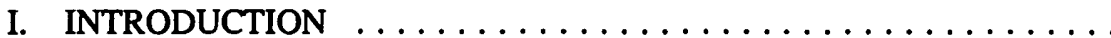

II. A CONSTITUTIONAL APPROACH TO ART . . . . . . . . . 477

III. THE CONSTITUTION OF MIND AND SOCIETY . . . . . . . 479

A. CONTRASTING FEDERALISMS $\ldots \ldots \ldots \ldots \ldots \ldots \ldots, 479$

B. DIFFERING IMAGINATIONS $\ldots \ldots \ldots \ldots \ldots \ldots \ldots \ldots, 482$

IV. THE LAWS OF PAINTING $\ldots \ldots \ldots \ldots \ldots \ldots \ldots \ldots \ldots \ldots, 483$

V. CONCLUSION $\ldots \ldots \ldots \ldots \ldots \ldots \ldots \ldots \ldots \ldots \ldots \ldots, 496$

Of the Department of Sociology and Anthropology, Concordia University, Montreal. Earlier versions of this paper were read at the 1987 Canadian Ethnological Society Conference at Laval University. and in the "Droits-Liberté-Démocratie" Intemational Colloquium at the 53rd A.C.F.A.S Congress, U.Q.A.M. I wish to thank both audiences, as well as three anonymous reviewers, for their many helpful comments. 


\section{INTRODUCTION}

This essay attempts to construct a bridge between two somewhat disparate disciplines: constitutional studies and the sociology of art. It uses the Canadian and American constitutions as frames for the analysis of the paintings of Alex Colville and Norman Rockwell, and their paintings as prisms for the illumination of the inner workings of the two constitutions. It is the writer's personal conviction that these two artists have more to tell us about our respective constitutions than such acknowledged experts as Peter Hogg or Lawrence Tribe. ' In any event, it is certainly the case that constitutional studies would be greatly enriched by expanding its focus to include the artistic as well as legal sources on the constitution. ${ }^{2}$

There are two reasons for concentrating on the works of Alex Colville (b. 1920) and Norman Rockwell (b. 1894 - d. 1979). First, a good case can be made for their being the most representative artists of their respective cultures. As Robert Fulford has observed of Colville's paintings,

Reproduced in magazines and books, on postcards and posters and television, they have become icons of Canadianism, the visual expression of our spirit - or at least, that part of our spirit we want at the moment to display to each other. ${ }^{3}$

As for Rockwell,

In America, Norman Rockwell is the best-known artist who ever lived. His subject is average America.

He has painted it with ... benevolent affection ... [He] describes the American Dream. ${ }^{4}$

In addition to appealing to mass taste (i.e., being reasonably "popular"), both artists have won state recognition. Colville, for example, was asked to design the coins for the Canadian centennial, while Rockwell was commissioned by the U.S. War Office to paint

See P. Hogg, Constitutional Law of Canada, 2d ed. (Toronto: Carswell, 1985); L. Tribe, American Constitutional Law, 2d ed. (Mineola, New York: Foundation Press, 1988).

The idea for this essay occurred to me while reading George Grant's English-Speaking Justice (Toronto: House of Ananasi, 1985). That book is dedicated to Alex Colville (and the poet Dennis Lee) for having "taught me about justice." What follows, then, is my attempt to reconstruct what Colville taught Grant about justice (in the sense of how to live right by the Canadian constitution). As I will be referring to Grant's work often, it may help to set out his definition of justice here at the outset. On Grant's account, "justice is not a certain set of external political arrangements which are a useful means to the realisation of our self-interests" (p.44). That is the theory put forward by the American philosopher John Rawls in $A$ Theory of Justice (Cambridge, Mass.: Harvard University Press, 1971). Rather, according to Grant, justice is "the very inward harmony of human beings in terms of which they are alone able to calculate their self-interest properly ... For justice is the inward harmony which makes a self truly a self ... a soul truly a soul" (p. 44-45). Later, when we come to speak of "psychic integration," what Grant means by "inward harmony" will become clearer.

3. $\quad$ R. Fulford, "Painter Laureate", Saturday Night (July, 1983) 5 at 5.

4. T. Buechner, Norman Rockwell: A Sixty Year Retrospective, (New York: Harry N. Abrams, 1972) at 13. 
Four Freedoms as part of its promotional campaign for the sale of U.S. war bonds. Whether one regards holding the title of "painter laureate," artist," as good or bad, the point is that such official recognition justifies our treating these two individuals as the most "representative characters" their countries have to offer, in the visual arts. ${ }^{7}$ Needless to say, were they not of equal public stature there would be no point to comparing their work, because the analogical proposition "Colville is to Rockwell as the Canadian constitution is to the American constitution" would not hold.

The second reason for concentrating on their work is historical rather than methodological. It has to do with Colville himself attributing his initial inspiration to become an artist to the many hours he spent as a boy pouring over the ad pages of the Saturday Evening Post. ${ }^{8}$ Many of these ads, not to mention the covers, were of course designed by Rockwell. Colville could therefore be identified as "the Canadian Rockwell." The reader may well object to this identification, for the tone of Colville's paintings is very different from Rockwell's: both artists paint ordinary people in everyday situations, but Colville's paintings have a distinctly menacing edge. This raises an important point: Colville aspired to be a Rockwell, but failed, and that failure was the condition of his success. ${ }^{9}$ Why couldn't he simply copy Rockwell and achieve success? The reason, I shall hold, is that it would have been ultra vires his constitution. Only by cleaving to the terms of the Canadian constitution the same way Rockwell conformed to the American could Colville achieve greatness.

\section{A CONSTITUTIONAL APPROACH TO ART}

We are familiar with there being constitutional limitations to the creation of legislation, not to the creation of art. But this is simply because our theories of art are not capacious or informed enough. One theory that does enable us to take a constitutional approach to the study of art is Gregory Bateson's "information theory" of the aesthetic process. According to Bateson, "art is a part of man's quest for grace" or "psychic integration", and each culture has its characteristic "species of grace" towards which its artists strive. ${ }^{10}$

5. Fulford, supra, note 3.

6. M. Tuzi, "Affirmation or Negation: The Art of Kurelek and Colville", Bridges (March, 1988) 5.

7. On the notion of "representative characters" - namely, individuals who provide "an ideal, a point of reference and focus, that gives living expression to a vision of life," see R. Bellah et al. Habits of the Heart: Individualism and Commitment in American Life (Berkeley: University of California Press, 1985) at 39.

8. A. Colville, "My Experience as a Painter and Some General Views on Art" (Sackville: Mount Allison University, 1951) [mimeographed].

9. If Colville does not really deserve the title of "the Canadian Rockwell" who does? William Kurelek, who ended up in a mental asylum. I am indebted to Arthur Kroker for this insight. There is no space to substantiate it, nor is there any need. It follows logically from my critique of Tuzi (who champions Kurelek against Colville). See infra notes 58 and 59.

10. G. Bateson, "Style, Grace and Information in Primitive Art" in Steps to an Ecology of Mind (New York: Paladin, 1973) at 255. 
"Grace", in Bateson's sense, entails the integration of the "reasons (or habits) of the heart" with the "reasons (or purposes) of the reason".

The "reasons of the heart" are not for Bateson, as they would be for those of a Freudian persuasion, the inchoate forces, pushes or heavings of the unconscious, but rather, "knowledge" which has been "sunk" - that is, knowledge internalized to the point of becoming habit. Bateson gives the example of a violinist: "Only the violinist who can control the quality of his notes [by force of habit or skill] can use variations of that quality for musical purposes"." By demonstrating skill, the violinist or painter communicates information about the "interlocking circuitry" of mind, or in other words, the articulation between conscious purposes and unconscious aptitudes. Such information has a "positive function in maintaining 'wisdom', i.e. in correcting a too purposive view of life and making the view more systemic." ${ }^{\prime 2}$

In addition to exhibiting skill, art objects contain redundancy or pattern. In elaborating on this point, which is central to his epistemology of art, Bateson emphasizes that it is "of prime importance to have a conceptual system which will force us to see the 'message ' (e.g. the art object) as both itself internally patterned and itself a part of a larger patterned universe - the culture or some part of it." ${ }^{13}$ What is meant here is that regardless of how "representational" or "realistic" a work of art might appear, its meaning lies not in what it depicts but in the relationships among its parts. Hence, according to Bateson, the task of the analyst is to spell out what sorts of relationships, correspondences and so on obtain both within the art object itself, and between its "compositional structure" and the structure of the culture.

Let me give a preliminary illustration of how Bateson's theory applies to the interpretation of Colville's art by simply juxtaposing two quotations. The first quotation is a description, in the artist's own words, of how he generates a painting:

What often happens is that I suddenly see that I can combine one idea with another, and both ideas then take on a significance that they would not have had on their own. It's a curious business of using rational processes and irrational ones - and they're going in a double hamess. ${ }^{14}$

The second quotation concerns the genesis, and on-going purpose, of the Canadian constitution:

the Canadian federation was inspired by a purpose altogether different from that which animated the American union. The purpose ... was to safeguard the permanence and to promote the expansion of two national cultures. It is here, in the essential partnership of two linguistic and cultural groups that one finds the dominant fact of Canadian nationhood. Here too, says the historian Arthur Lower, 'is the most

II. Ibid. at 252 .

12. Ibid. at 250.

13. Ibid. at 237.

14. Quoted by H. de Santana, "Colville: The Order and the angst" (1986) 29 Equinox 69 at 77. 
resounding note in our history, the juxtaposition of two civilizations, two philosophies, two contradictory views of the fundamental nature of man. ${ }^{\cdot 15}$

The import of reading these two quotations together is that the mode in which ideas are combined in a Colville painting mirrors the "juxtaposition of two civilizations, two philosophies" under the Canadian constitution.

We have acquired a preliminary sense of the characteristic "species of grace," or form of "psychic integration," toward which the Canadian artist strives: the simplest word for it is "juxtaposition." What is the corresponding "species of grace" for the American artist? To answer this question we must first inquire into the purpose which animated the American union. That inquiry is undertaken in the next part of this essay, which also seeks to document how two distinct ways of thinking follow from the differences in the mode of organization of the Canadian and American state. Having described how the habits of the American mind differ from those of the Canadian mind, we shall finally be in a position to analyze how the art of Rockwell and Colville gives expression to these contrasting "algorithms" (the subject of part IV). ${ }^{16}$

\section{THE CONSTITUTION OF MIND AND SOCIETY}

\section{A. CONTRASTING FEDERALISMS}

Both Canada and the United States are federal states, but the division of powers between the federal and provincial (or state) governments is very different. In the United States, the whole (as represented by Washington) is greater than its parts; in Canada, the whole (as represented by Ottawa) is on a par with them. Interestingly, the current division of powers is virtually the reverse of that contemplated in the original constitutions of the two countries. It was the intention of those who framed the U.S. Constitution that the Union be an alliance among equal centres of power - that is, a system of "co-ordinate federalism". By contrast, the Fathers of Confederation meant Canada to be a unitary state controlled from the centre - that is, a legislative union much like Great Britain, or what is known in the literature as a system of "subordinate federalism." 17 The two countries have thus been evolving in opposite directions both from themselves (that is, their original constitutions) and from each other since their creation: the U.S. toward a system of subordinate federalism, Canada toward a system of coordinate federalism.

This helps to explain why the so-called "American identity" is so strong while the Canadian identity is so weak or fragmented. Canada lacks a centre. Colville put this point very well when he wrote in an essay entitled "On Being a Canadian":

E. Black, Divided Loyalties: Canadian Concepts of Federalism (Montreal: McGill-Queen's University Press, 1975) at 173.

16. Bateson, supra, note 10 at 250.

17. See generally Black, supra, note 15; M. Greenwood, "Lord Watson, Institutional Self-Interest, and the Decentralization of Canadian Federalism in the 1890s" (1974) 9 U.B.C. L.R. 244. 
Canada is, I think, less coherent than the U.S., less of a melting pot, more a "community of communities" - a concept which I believe comes from Martin Buber. Thus in Canada it is possible to belong both to the country as a whole and at the same time to a unique segment of $\mathrm{it}$, as I belong to the Maritimes. ${ }^{18}$

As this quotation reveals, in Canada the whole is not greater than its parts but on a par with them.

One of the reasons the Canadian identity remains so divided or "regionalized" is that Canada, unlike the United States, has never had a civil war. The American Civil War abolished the distinction between North and South, and thus gave substance to the "unity of we" first spoken in the Declaration of Independence and reiterated in the Preamble to the Constitution:

We the People of the United States, in order to form a more perfect Union, establish Justice, ... and secure the blessings of Liberty to ourselves and our Posterity, do ordain and establish this Constitution

What is comprehended by the use of the term "we" in this declaration is best explained by James White:

The 'one people ' the Declaration seeks to create [and the Preamble to the Constitution reiterates] is not a diverse people, different in talents and interests, in mode of life, in character and manners - not a nation as [Edmund] Burke has taught us to conceive it. It is a single whole, a single person, as it were, with a single set of sentiments and determinations. ... 'We' are blended into a single 'one ', the stated ideal of equality among people becomes an ideal of a very different sort, of merger into a common identity..$^{19}$

Various other features of the U.S. Constitution may be seen as contributing to the formation of this "single whole" or "unity of we." The structure of that unity is best understood by way of contrast to the "divided whole" or "unity of you and I" which the Constitution Act, 1867 (formerly the British North America Act) set in place.

To begin with, the U.S. Constitution is monolingual, it recognizes no other language than English. By contrast section 133 of the Constitution Act recognizes both English and French for legislative and judicial purposes. Furthermore, the U.S. Constitution is resolutely egalitarian whereas the Constitution Act envisions a hierarchically ordered society. ${ }^{20}$ For example, the U.S. Constitution prohibits the granting of any title of nobility (Article 1, section IX.8), it prohibits Congress from privileging or proscribing any

18. A. Colville, "On Being a Canadian" (unpublished ms., in the writer's possession).

19. J. White, When Words Lose Their Meaning: Constitutions and Reconstitutions of Language, Character and Community (Chicago: University of Chicago Press, 1984) at 238-39.

20. See P. Resnick, "Montesqui Revisited, or the Mixed Constitution and the Separation of Powers in Canada" (1987) 20 Cdn. J. of Political Science 971; D. Howes, "Property, God and Nature in the Thought of Sir John Beverley Robinson" (1985) 30 McGill L.J. 365. 
given religion (1st Amendment), and it extends the "equal protection of the laws" to every citizen (14th Amendment).

By contrast, the Constitution Act does not outlaw titles of nobility. ${ }^{21}$ This is the first way in which it seeks to create a nation as Edmund Burke taught us to conceive it - a nation of diverse people. That nation is best described as a "vertical mosaic,"22 given the way Protestants and Roman Catholics are guaranteed the right to "separate schools" by section 93, and therefore derive more benefit or protection from the Constitution than do those who belong to other denominations. Furthermore, there are no provisions regarding the protection of individual rights and freedoms in the Constitution Act. "Prior to 1982, constitutional law in Canada, with a few exceptions, was limited to disputes between levels of government, and did not extend to disputes between the individual and the state. ${ }^{23}$ Indeed, "individual rights" were only protected to the extent that those pieces of legislation which infringed upon them represented violations of the division of powers under sections 91 and 92 , and so could be declared ultra vires the government (federal or provincial) which enacted them.

This situation might seem to have been altered by the enactment of the Canadian Charter of Rights and Freedoms, 1982, but the change was not as drastic as many people think. For example, the Charter "guarantees" the rights and freedoms set out in it, but at the same time subjects them to "such reasonable limits prescribed by law as can be demonstrably justified in a free and democratic society." Similarly, section 15 of the Charter recognizes a "right to equality before and under the law" but qualifies this right not to be discriminated against by at the same time sanctioning affirmative action programmes (which could be seen as a form of "reverse discrimination"). There are other aspects to the Charter which distinguish it from the U.S. Bill of Rights, such as the recognition it gives to rights of a collective nature (minority language educational rights in section 23, aboriginal rights in section 35), and the proviso in section 27 that the Charter be interpreted in a manner consistent with the "multicultural heritage of Canadians".

The society contemplated by the Canadian Constitution, with its stress on "peace, order, and good government," contrasts starkly with the situation in the United States, where the emphasis is instead on "life, liberty, and the pursuit of happiness." This emphasis on "liberty" at the expense of "order" has proved a real stumbling block for ethnic collectivities in the U.S. The latter often feel cheated of recognition. Their problem, as

This is why many former Prime Ministers and Chief Justices, as well as numerous industrial magnates, are known as "Sir So-and-So." This practice lapsed in the 1930s: today there is only the Order of Canada. But the contrast with the U.S. stands: the highest title to which any individual (including the President) has ever been able to aspire in the U.S. is that of "Mister" - as in "Mr. President."

22. J. Porter, The Vertical Mosaic: An Analysis of Social Class and Power in Canada (Toronto: University of Toronto Press, 1965).

23. P. Macklem, "Constitutional Ideologies" (1988) 20 Ottawa L.R. 117 at 118-19. 
Allan Bloom points out, is that "the Constitution does not promise respect for blacks, whites, yellows, Catholics, Protestants or Jews. It guarantees the protection of the rights of individual human beings." ${ }^{24}$ But, at least in the U.S., English-speaking Protestants and French-speaking Catholics are not privileged over all other linguistic and religious denominations, as they are in Canada.

To sum up, the U.S. Constitution does not permit one to affirm one's membership in a particular group, only one's rights as an individual against the state (i.e. one's individuality) or one's rights as a citizen (i.e. one's nationality). The Canadian Constitution, on the other hand, downplays individuality and nationality in order to preserve the pact between the two so-called "founding peoples" - the English and the French - on whose alliance (as opposed to "perfect Union") the survival of the country rests. Hence the fact that neither "American individualism" nor "American nationalism" has any counterpart in Canada. "Canadian individualism" simply makes no sense. There is such a thing as "Canadian nationalism" but it is offset by Quebecois nationalism and the various regionalisms: Western, Maritime, etc. This is in accordance with the principle that the whole is not greater than its parts but on a par with them.

\section{B. DIFFERING IMAGINATIONS}

We have seen that the U.S. Constitution is a "unifying constitution," one under which the stated ideal of equality among people gives way to merger into a common identity, a "melting pot." By constrast, the Canadian Constitution is a "juxtaposing constitution", in that it is designed to safeguard the essential partnership of two linguistic and cultural groups, and by so doing gives rise to a kind of "vertical mosaic." Given this knowledge of the contrasting infrastructures of the two societies, we are now in a position to explore certain respects in which their habits of mind may differ.

I would suggest that the American mind is organized concentrically and its characteristic mode of operation is "synthetic." Take the case of the song We Are The World: this song extends the "unity of we" discussed previously to encompass the whole world. ${ }^{25}$ To put this another way, the U.S. imagination unfolds along a continuum, with the individual at one end and the nation (or perhaps the world) at the other, incorporating everything in its wake. Consider, for example, the following quotation from a Time correspondent commenting on the 200th anniversary of the Constitution of the United States: "Walt Whitman wrote, 'I contain multitudes'. That is what the Constitution does - an astonishing feat considering the variety of multitudes that have landed on American shores, and continue to land."26 As this quotation suggests, the logic of the American mind is one of "incorporation."27

A. Bloom, The Closing of the American Mind (New York: Simon and Schuster, 1987) at 33-34. See D. Howes, "'We Are the World' and Its Counterparts: Popular Song as Constitutional Discourse" (1990) 3 Intemational Journal Pol. Cul. and Soc. 315.

L. Morrow, "The Ark of America" Time (July 1987) 21 at 21.

D.H. Tumer, Life Before Genesis (New York: Peter Lang, 1985). As distinct from "confederation." 
By contrast, the Canadian mind is organized bicentrically and its characteristic mode of operation is "diathetical." The simplest example of what I am here calling a "diathesis" (which may be defined as "the affirmation of two mutually contradictory theses or positions at once"), is given in the name of the Progressive Conservative party. It is patently contradictory for a political party to call itself progressive and conservative at the same time, yet Canadians see nothing unusual in this name. The logic of the Canadian mind is one of "confederation." Armour and Trott, in their classic study of the history of English Canadian philosophy, give an apt summary of how this tendency to "reason federally" (or combine apparently contradictory ideas) works in practice:

Dominantly in English Canadian philosophy, reason is used as a device to explore altematives, to suggest ways of combining apparently contradictory ideas, to discover new ways of passing from one idea to another. Only rarely is it used as an intellectual substitute for force - as a device to defeat one's opponent, to show his ideas to be without foundation, or to discredit his claims to philosophical thought. There is, in short, a kind of philosophical federalism at work, a natural inclination to find out why one's neighbour thinks differently rather than to find out how to show him up as an idiot. ${ }^{28}$

American philosophy, by contrast, which is informed by the tendency to "reason pragmatically," rarely displays the same respect for and openness to alterity. ${ }^{29}$

As a last example of the bicentricity of the Canadian mentality, consider the following character sketch from Doris Lessing's The Golden NoteBook:

Ella gets the idea of this character from the Canadian scriptwriter - from his cool and mask-like attitude as a lover: he was watching himself in a role, the role of a married man with a mistress. It is this aspect of the Canadian that Ella uses - a man watching himself play a role. ${ }^{30}$

The doubling of consciousness and the intense awareness of boundaries evoked in this passage contrasts starkly with the image of Whitman's ego expanding to contain all the people of the United States.

\section{THE LAWS OF PAINTING}

Having described how the habits of the American heart differ from those of the Canadian, we are now in a position to analyze how the art of Rockwell and Colville gives expression to these contrasting "algorithms." But before spelling out their differences, let us review what makes them similar and therefore comparable.

28. L. Armour \& E. Trott, The Faces of Reason: Philosophy and Culture in English Canada 1850-1950 (Waterloo: Wilfrid Laurier University Press, 1981) at 4.

29. See J.D. Rabb, "The Polycentric Perspective: A Canadian Altemative to Rorty" (1989) 28 Dialogue 64.

30. D. Lessing, The Golden Note-Book (London: Grafton Books, 1973) at 448 . For a further development of this theme see G. McGregor, "A view from the fort: Erving Goffman as Canadian" (1986) 23 Can. Rev. of Soc. and Anthr. 531. 
First, as noted in the Introduction, they are equally prominent, the most representative artists of their respective cultures. Second, Rockwell's cover illustrations for The Saturday Evening Post may be said to have inspired Colville to become an artist, albeit indirectly. Third, both take the ordinary as their subject matter. "I do ordinary people in everyday situations and that's about all I can do," Rockwell once said, ${ }^{31}$ and as Hellen Dow has observed of Colville's work, "Colville celebrates the ordinary." 32 Fourth, neither stands within the mainstreams of "contemporary art" as this has developed within their respective countries. For example, Rockwell poked gentle fun at current trends in his painting The Connoisseur, which depicts a typical middle-aged, middle-class man (balding and pudgy) staring befuddledly at the drips and splotches of a Jackson Pollock "action painting." As for Colville, he has never had anything but contempt for the "mad message bearers" of Abstract Expressionism. ${ }^{33}$ This helps to explain why art critics sympathetic to the abstract camp in art, such as John Bentley Mays of the Globe and Mail, have reacted with equally sharp contumely to Colville's paintings:

the art [Colville] has made is virtually of no creative consequence within the history of Canadian painting and graphic design, except, perhaps, as a footnote to some paragraph on the fate of the magazine illustration style of the $1930 \mathrm{~s}^{34}$

Finally, both Rockwell and Colville have been vindicated (against the likes of John Bentley Mays), since the "triumph" of Abstract Expressionism proved to be short-lived, and "Realism" has come round again: "most of the important American painting of the eighties is either explicitly representational or deals with metaphors for landscape or the figure." ${ }^{135}$

When I say that "Realism" has come round again, I am referring to the genre of American Luminism. That genre is characterized by "an appearance of extreme literalness whilst creating a haunting atmosphere of stillness and silence, even in scenes of great animation." 36 This genre, first exemplified in the paintings of Thomas Eakins, was dominant at the turn of the century, and persisted through the near-abstract paintings of industrial scenes by the Precisionists (Charles Sheeler, Niles Spencer), as well as the works of Andrew Wyeth, Paul Cadmus, Edward Hopper and George Tooker. A number

31. N. Rockwell \& T. Rockwell, Norman Rockwell: My Adventures as an Illustrator (New York: Harry N. Abrams, 1988) at 349.

32. H. Dow, The Art of Alex Colville (Toronto: McGraw-Hill, 1972) at 104.

33. Quoted in R. Skoggard, "Old Master" Saturday Night (May, 1988) 89 at 89 . It bears noting that Rockwell did experiment with Picassoesque techniques in the 1920s, but his editors encouraged him to stop. See Buechner, supra, note 4 at 47.

34. Quoted in Skoggard, ibid. at 89.

35. B. Rose, American Painting: The Twentieth Century (New York: Rizzoli, 1986) at 155 . Rose continues: "energetic abstract art [nevertheless] continues to be done by artists in their forties who are also drawing on the legacy of Abstract Expressionism, reacting as well against the cold, reductive and mechanical styles of Pop and Minimal art."

36. Anon., Alex Colville (London: Marlborough Fine Art Ltd., 1970) at 6. See further J.L. Ward, American Realist Painting 1945-1980 (Ann Arbor: U.M.I. Research Press, 1989). 
of critics ${ }^{37}$ have suggested that Colville's paintings belong to this submerged genre (submerged in the sense of being marginalized by the rise of Abstract Expressionism. And they do, to an extent even greater than Rockwell's paintings, which are literal, but are never still or silent. ${ }^{38}$ However, it is the specifics of Rockwell's and Colville's "realisms" that concern us here. (Colville's differences from the other American painters mentioned above will be dealt with in the footnotes to the following text.)

The primary reason for Rockwell's "realism" is that he felt "uneasy about making up pictures 'in his head' as he would say." 39 He had to have a model or photograph in front of him in order to draw. In fact, all of his paintings from the 1930s onwards are tracings (using an opaque projector) of the pictures he took during photographic sessions involving countless friends and neighbours as models. As Susan Meyer notes, "The strong kinship Americans felt for the personalities depicted in Rockwell's work derived, in large part, from the authenticity of the subjects themselves: they were real. ${ }^{140}$ Asked to paint a sheriff or a country doctor, Rockwell went and got the local sheriff or doctor to pose for his camera. Meyer continues, "In a sense, Rockwell was a realist: he happened to view the American way of life with constantly renewing optimism, but he drew from genuine sources." ${ }^{11}$

One finds the same striving after visual truth in Colville's paintings, but the truth of a Colville painting is transcendental rather than empirical. ${ }^{42}$ As Colville has written,

because an artist must conceive as well as perceive if he is to present the full implications of his subject, I work in an indirect way. By painting largely 'out of my head' and by using an arduous technique, I aim to produce paintings which are constructions on a flat surface, each with an individual identity. ${ }^{43}$

37. Anon. ibid.; D. Burnett, Colville (Toronto: Art Gallery of Ontario, 1983) at 112-13.

38. Of course, the conventions of early twentieth century American illustration influenced Rockwell's style as well. See Buechner, supra, note 4 at 34 . These conventions have also made a comeback in the last years. See D. White, "The New Rockwellians" 321 Design (September 1975) 54. "This year's European illustration annual proves the rising strength of Rockwellian realism in advertising," says White.

S. Meyer, Norman Rockwell's People (New York: Harry N. Abrams, 1981) at 65.

Ibid.

41. It has been said that in America "progressive faith is... fact." Grant, supra, note 2 at 9. That is, optimism is not opposed to "realism," but intrinsic to it.

42. Another way of putting this would be that Colville's paintings are Aristotelian or Thomistic in design, while Rockwell's paintings resonate with the pragmatism of James or Dewey. The former's paintings are open to eternity, the latter's to experience. Compare Grant, supra, note 2 and J. MacDermott "The Morality of Experience" in De Marco and Fox, eds, New Directions in Ethics (London: Routledge and Kegan Paul, 1986). According to Rose, supra, note 35 at 11, "Pragmatic literalism" is one source of American art, but there is also "visionary Transcendentalism." As examples of the latter "genre" she cites some expressionist works by Georgia O'Keefe, Bill Jensen and Sam Francis, which try to convey "transcendental emotional experience." Suffice it to say that a Thomist would not be impressed by the "mad messages" those works express - they lack the requisite rational order. Quoted in Dow, supra, note 32 at 89 [emphasis added]. 
Thus, Colville's depiction of things is not dictated by the technology of the camera. He may sometimes use photography "as an aid at a specific point in the process of a work," but not as "a point of departure. "144 Instead, he begins with imaginative sketches, which he proceeds to "authenticate" (a process which may take months, or even years) by doing life drawings of the figures of his imagination, proportioned according to the modular structure he has chosen for a given painting. ${ }^{45} \mathrm{~A}$ Colville painting both tells a story and teaches one a lesson in geometry. Hellen Dow explains:

His paintings are rationally constructed on a mathematical system of harmonic proportions. The artist freely selects this modular arrangement, with the firm belief that by deliberately limiting his formal composition in this way, he actually gains freedom of expression. For it is only under the control of a rational order that he is free to achieve the highest and most profound possibilities of his art. "Limitation is freedom" he declares. ${ }^{46}$

The declaration "Limitation is freedom" recalls to mind the vision of ordered liberty enshrined in the Constitution Act, 1867, as discussed earlier, and in particular the phrase "peace, order and good government" as opposed to the American "life, liberty and the pursuit of happiness".

It is no accident that Colville makes paintings with titles like Ocean Limited (the name of the Halifax-Montreal express train) and Nude and Dummy. ${ }^{47}$ The latter painting takes a bare attic room as its setting, within which a nude woman standing at the window looks back over her shoulder at a dressmaker's dummy. As David Burnett notes, "The purpose of a dummy is wholly contained in the notion of measurement. ${ }^{148}$ The painting, in other words, is as measured as it is about measurement. The titles of Rockwell's paintings have a different ring: his magnum opus, Four Freedoms, consisted of four panels depicting Freedom of Speech (a man rising to speak out at a town meeting), Freedom of Worship (a mass of people praying together), Freedom from Want (a family sitting down to a Thanksgiving dinner) and Freedom from Fear (parents tucking their children into bed). The last two freedoms are nowhere mentioned in the U.S. Constitution, but they are no doubt implied.

According to the analysis which is beginning to take shape here, Colville gives expression in his paintings to the values (or better, the image of the good) inherent in the Canadian constitution. An art critic might object to this that Colville himself has

\footnotetext{
44. Bumett, supra, note 37 at 136.

45. Ibid. at 19-20.

46. Dow, supra, note 32 at 33.

47. For ease of reference, all works mentioned in the following text can be found either in D. Burnett's Colville supra, note 37 or C. Finch's Norman Rockwell's America (New York: Abrams, 1975). 
proclaimed it "ridiculous to be self-consciously Canadian or to make self-conscious attempts to produce a Canadian art ... one wants to be good. ${ }^{.49}$ The same critic goes on:

The indigenous painting which first endowed Canadian art with self-confidence and direction was the landscape work of the Toronto men who are known as the Group of Seven. Apart from his overwhelming concem for natural environment, however, Colville has nothing in common with these painters. Indeed, beyond the Post-Impressionism of his teacher, Stanley Royle, who was a product of English Schools, he has no stylistic heritage in Canada at all. In truth, his most significant teacher has been nature itself ....

It is typical of the sociological naivete of the art critic that Dow, whose analysis of Colville's oeuvre otherwise contains many deep insights, should yet think that Colville has direct access to nature, that his perception is not mediated in the least by the structure of the society in which he lives. If that were true, there is no reason his paintings should be any different from Rockwell's or those of the American Realists, but they are, which suggests that his perception of the world must be influenced by his constitution.

Besides, there is the intriguing fact that "Colville himself defines his creative impulse with a phrase borrowed from Joseph Conrad: 'I try to do the highest possible justice to reality. "'51 "Doing justice to reality" involves something more than letting nature be one's teacher. On the strength of this remark alone, then, we are encouraged to explore how the justice he does to nature can be seen to bear the imprint of the conception of justice inherent in the Canadian constitution.

Consider the painting Couple on Beach. In this work, a woman lies on the sand with a sun hat covering her face, a man crouches in front of her looking out to sea. Significantly, the figures cast no shadows, and their contours are perfectly delimited. If the woman was "really" lying on the sand, it would have obscured part of her figure. But it does not. She is wholly self-contained, as is the man (look at his feet).

Why has Colville eliminated anything (shadows, sand) which might confuse or blur the boundaries of these figures? Perhaps because justice requires of us that we "think of a

Quoted in Dow, supra, note 32 at 96 . What Colville means by "good" is something more than "popular," or as he says "popular, but good." The meaning "goodness" has for Colville is best explained by George Grant in Technology and Justice (Toronto: House of Ananasi 1986) at 42: "In the old language 'good' means what any being is fitted for. It is a good of animals to breathe; we are not if we do not. ... Human beings are fitted to live well together in communities and to try to think openly about the nature of the whole." heritage in Canada (a proposition I find doubtful), he certainly created one. One thinks of the paintings of two of his former students, Christopher Pratt and Tom Forrestall, as well as Ken Danby. de Santana, supra, note 14 at 70. 
[VOL. XXIX, NO. 2 1991]

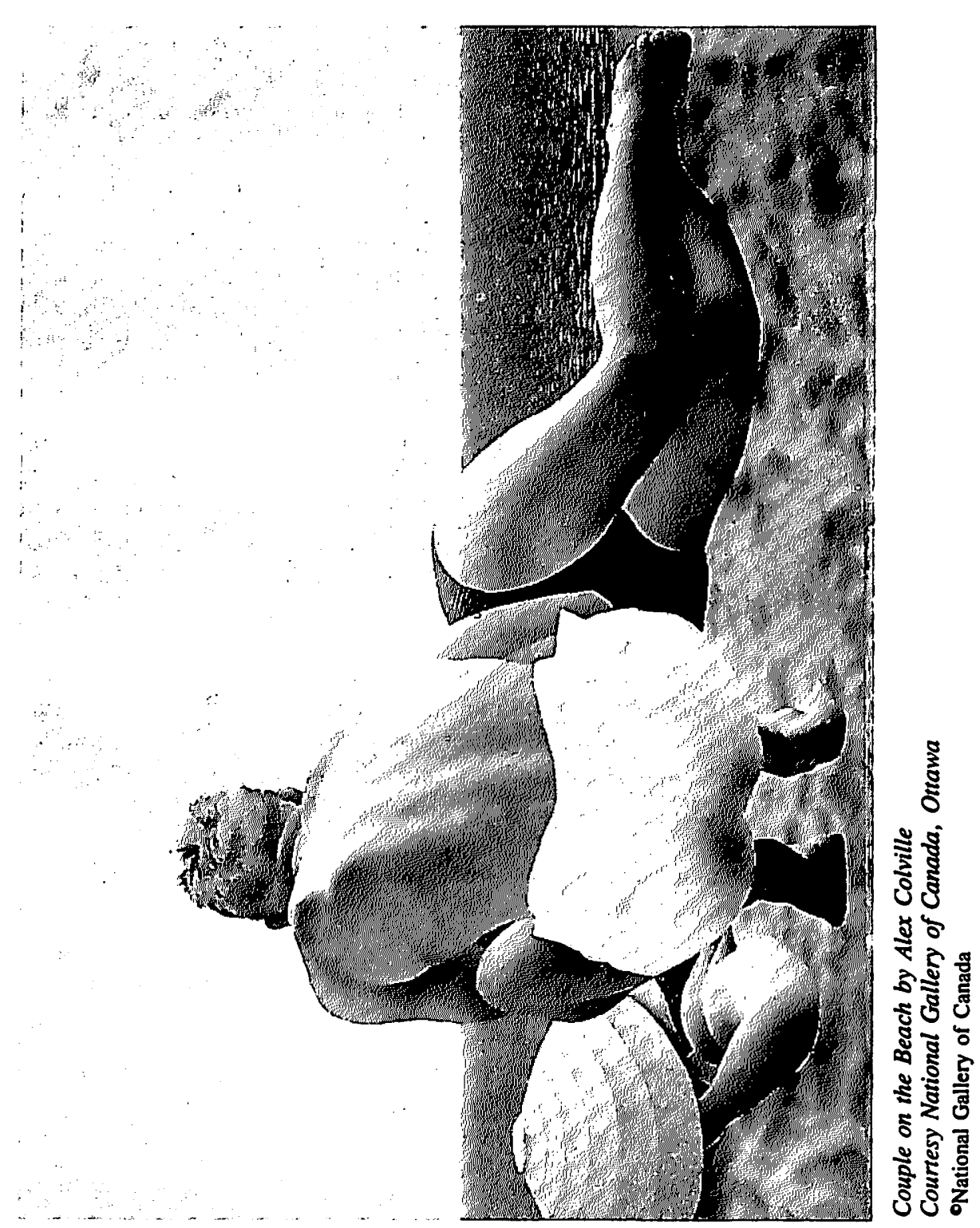


system of provinces, co-existing side by side, with clearly marked boundaries"; for any element in this system (as in the painting) to encroach upon another would be an injustice - each must keep within bounds. ${ }^{52}$

The mood, or atmosphere, of Couple on Beach is best described as one of double solitude. The couple is together, but apart, their attention turned in different directions. This is a constant theme in Colville's paintings. In June Noon, a woman undresses inside a tent, a man with binoculars stands outside scanning the horizon. In January, a woman on snowshoes turns in the direction of the horizon, a man wearing sunglasses faces the spectator. At one level, these paintings give expression to Colville's ideas about inter-personal relationships: "I am inclined to think that people can only be close when there is some kind of separateness." ${ }^{\text {53 }}$ At a deeper level, they are expressions of the "unity of you and I", of the alliance between two distinct linguistic and cultural groups, which is at the base of the Canadian confederation. Given that the woman in these paintings is Colville's wife Rhoda, it follows that he lives the constitution even in his private life. ${ }^{54}$

We have seen how the justice Colville does to reality involves constructing it in the image of the grid which the Canadian constitution imposes upon reality. The justice of a Colville painting, which Dow took to be "natural," is in fact constitutional. Why has Dow mistaken a constitutional for the natural way to paint? Perhaps this is because the Canadian conception of justice is more natural than contractual. In Grant's words: "justice is the overriding order which we do not measure and define, but in terms of which we are measured and defined" - it is "what we are fitted for" rather than something we "bargain for" (as the Social Contract theorists hold) or "establish" ourselves. ${ }^{55}$ As is well-known, the Americans established (i.e. made) their constitution whereas Canadians were given theirs (i.e. had it defined for them) by the Imperial Parliament at Westminster.

The "grace" or "psychic integration" to which Rockwell gives us access in his paintings is very different. Instead of co-existing side by side, people touch each other. In Looking Out to Sea, a boy and his grandfather face in the same direction, the old man's left arm encircling the boy's shoulders. In Planning the Home and First of the Month (a series of ads Rockwell did for a life insurance company), a young couple is shown going over some architectural blueprints and calculating how to pay the monthly bills respectively. As Christopher Finch observes, these situations are depicted in "good humoured but

52. F.M. Cornford, From Religion to Philosophy (New York: Harper Torchbooks, 1957) at 71, 55-63. I have borrowed Cornford's account of the ancient Greek conception of justice because it fits the Canadian setting, as I have shown elsewhere. See Howes, supra, note 20.

53. Quoted in Burnett, supra, note 37 at 108.

54. It would be interesting to know whether Colville has ever addressed his wife as "Honey." I strongly doubt it, for "Honey" has the connotation of a sticky, gooey (synthetic) mass. It would have been ultra vires the constitution for him to address her this way. 
slightly idealized terms ... [idealized] in the sense that these paintings tend to show man and wife thinking as one person" - that is, as a "unity of we". ${ }^{56}$ It is the indivisible unity of the couples Rockwell depicts that constitute their most endearing quality. Indeed, even when spouses appear to have quarrelled, as in The Debate, where a husband and wife sit back to back, and from the papers they are holding it appears that they support rival political candidates (Harding vs. Cox), the most significant fact is that their faces are already turning in the same direction, which suggests that they will soon see eye-to-eye again.

Another theme to which Couple on Beach gives expression is the theme of contemplation. In Colville's own words, "What is being contemplated is the woman, the sea and sky." ${ }^{17}$ It is good to contemplate, according to Colville. And he encourages us to do so repeatedly, as in Visitors are Invited to Register (a man contemplates - or "registers" - the interior of a church), In the Woods (a masked man takes aim with a gun, but the safety is on) or Target Pistol and Man (a self-portrait in which the artist locks eyes with the spectator, a target pistol lying on the table in front of him). It bears underlining that those who perceive the latter picture as menacing or sinister are not contemplating it adequately. A target pistol is not designed to kill; it is designed to improve one's concentration, one's aim.

This brings us to the subject of angst in Colville's paintings. One of Colville's most unenlightened critics, Marino Tuzi, has characterized his work as "a mechanical geometry of angst". Consider Pacific, for example: a man, naked from the waist up, with his back turned to the spectator, leans against the doorframe of a house overlooking the sea, in the foreground a pistol lies on a table that is etched with a ruler. According to Tuzi: "It is the gun and virility, implied menace and violence, couched in a flawless aesthetic order that rule the painting." 58 This reading of the painting is fundamentally flawed. What rules the painting is the one detail Tuzi overlooks, namely the ruler stretched out along the table. The ruler stands for measurement. The man, meanwhile, is contemplating the infinity of the ocean. Just as the ruler balances the gun, so the infinity of the ocean balances the virility of the man. Were Tuzi to reflect upon the relationships between the objects in this painting, instead of focusing on the objects themselves, he might have grasped its meaning. The meaning of a Colville painting is always in the balance. Tuzi unwittingly recognized this when he wrote: "The idea that Canada is a fragmented, regionalized country, holding itself precariously together on the edge of existential negation, achieves complete legitimation in Colville's work"..$^{59}$ That Tuzi cannot himself see Canada this way proves that he has learned nothing from Colville's work.

If Colville's paintings are about how to think, then the painting that calls upon us to think the hardest is Horse and Train: a horse gallops down a railway track, a train 
approaches from the opposite direction. David Burnett evokes this painting well: "The images jolt us by their unexpected juxtaposition and angles, and they contain the apprehension of disaster. ${ }^{160}$

The inspiration for this painting is known to have come from a poem by the South African writer, Roy Campbell:

\section{Against a regiment I oppose a brain}

And a dark horse against an armoured train.

What must have appealed to Colville about this poem is its diathetical structure: it advances two theses at once. The poem, like the painting, is open to a variety of interpretations. One can read it as being about the opposition between nature and machine, or the opposition between the unconventional artist and conformist society, as Hellen Dow does. Or one can read it as a constitutional document, and see the juxtaposition of images as being about the division of powers between the provincial and federal governments, for example, or the relationship between individual rights and collective rights, or the "essential partnership," (between the English and the French). But to ask, as Dow does: "Which will conquer, nature or machine, creation or destruction, Providence or chance?"61 is not appropriate. To think in terms of conquest, or "winning", is to think synthetically instead of diathetically, to posit a "unity of we" as the end of history instead of a "unity of you and I." Colville's point, I think, is that horse and train must be thought as an ensemble, as a "divided whole" not a "single whole." That is why there is no temporal dimension to this painting: time is frozen in space. As in all his work, history stands in suspense.

By contrast, there is always something happening in a Rockwell painting. In No Swimming, for example, three half-dressed boys and a dog are shown dashing past a "No Swimming" sign, and one expects to see the outraged owner of the water hole burst into the picture from the right. Buechner has commented on the "fascination with time" visible in this and other Rockwell paintings: "Although he records precise moments, he wants the viewer to know what has just happened or will happen next."62 Indeed, one can no more get outside of "time" or "history" looking at a Rockwell than one can get outside of technology. As will be recalled, Rockwell's perception of events was mediated by the camera lens. ${ }^{63}$ There is an intimate connection between history and technology, such as the camera. Technology involves the union of knowing (logos) and making

60. Bumett, supra, note 37 at 96.

6. Dow, supra, note 32 at 41 .

62. Buechner, supra, note 4 at 114.

63. The same was true of the American Precisionist Charles Sheeler's work. His "reduction of forms to their pure geometric volumes," as in the painting Rolling Power, was derived "from his photography." Rose, supra, note 35 at 26. This is what distinguishes Sheeler's work from Colville's: the latter does not work from photography, but "out of his head". See supra, note 43. 
(techne), and thus renders everything we know "historical" - that is, devoid of a transcendental purpose. ${ }^{64}$

As one reflects further, more differences between the two artists' styles become apparent, all of which can be related to the differences in their constitutions. Colville's work is clinical, Rockwell's sentimental. As Meyer notes, the latter was always on the look-out for situations that would make the spectator "want to sigh and smile at the same time". ${ }^{65}$ This surplus of emotions was further augmented by the "extra attention" Rockwell gave to the faces of those he drew. ${ }^{66}$ It is for this reason that the personalities of "Rockwell's people" stand out so strongly. Colville's people, by contrast, are often faceless, expressionless, their backs turned to us. ${ }^{67}$ It is as if the idea of individuality were less developed in Colville's paintings than in Rockwell's.

This fact is consistent with the historically lesser interest in individual rights (and the expression of individualism) in Canada than in the U.S.

A second major difference has to do with the representation of space. There is as strong an emphasis on proximity in Rockwell's paintings as there is on distance - infinite expanses - in Colville's. Rockwell "likes his backgrounds close in"; "It is almost as if the incidents that he illustrated ... took place in shallow boxes." ${ }^{168}$ Compare the warm light and cozy interior of Rockwell's Shuffleton's Barber Shop with any of Colville's paintings, where the inner space of a room is always juxtaposed to the infinity of the land, the sky or the sea. The closeness of Rockwell's interiors, like the empty spaces of Colville's, contribute to their emotional tone. As Mary Douglas has observed, "More spacing means more solemnity." ${ }^{169}$ Colville's paintings are never happy.

It is said that Rockwell's art took a "political turn" in the 1960s, as he, along with many other Americans, became more sensitive to civil rights issues. ${ }^{70}$ This new rights consciousness is reflected in The Problem We all Live With: a little black girl marches to school surrounded by four U.S. deputy marshalls. This painting is about the "problem" of integration, of achieving a veritably "perfect Union." Another painting which gives

It has been observed that: "The painter Andrew Wyeth employs rather similar devices [i.e. figures that turn their backs toward us], but for what seem to be other reasons. I think he fears that direct confrontation with the model might weaken his objectivity, cause him to relent: he is more concerned with portraiture than with situation, and conveys an almost suffocating sense of identity by means of an intimate examination of posture, apparel and setting." Anon., supra, note 36 at 8. Thus, Wyeth, heightens one's sense of individuality by means of the same devices Colville uses to suppress any sense of same.

68. Buechner, supra, note 4 at 135; Finch, supra, note 47 at 25.

$\rightarrow$ Quoted in Howes, supra, note 25.

70. Meyer, supra, note 39 at 212 . Though it was not the case that Rockwell's "personal politics [shifted] - he had always been a liberal," and he continued to be a liberal. Ibid.
} 
expression to this rights consciousness is The Right to Know (which one presumes was inspired by the Watergate Scandal): a great mass of people, both young and old, hippie and straight, look directly at the spectator from the other side of a judge's bench. This painting is about the democratization or popularization of wisdom: there should be no unevenness to the distribution of knowledge. ${ }^{71}$

There is something vaguely disconcerting about The Right to Know. Perhaps this is because no one shows any signs of having been illuminated by the knowledge they've acquired through the exercise of their "democratic right". ${ }^{72}$ Or perhaps it is because it is alarming to see so many people so closely crowded together. According to Buechner, the first painting in which Rockwell massed people in this way was Freedom of Worship, painted in $1942 .^{73}$ The inscription on that painting reads: "Each according to the dictates of his own conscience." The most famous painting in which Rockwell piles people into the canvas is The Golden Rule. That painting depicts representatives of all (or virtually all) the nations of the world, in traditional costume, arranged like a chorus. The inscription on it reads: "Do unto others as you would have them do unto you." A more fitting inscription might have been the 60 s Coke commercial which went: "I'd like to teach the world to sing in perfect harmony ..."

The idea that everybody should be treated the same as you treat yourself is a beautiful idea, and it is certainly much easier to apply than that other, more archaic definition of justice which is: "To render each human being their due." ${ }^{174}$ The latterdefinition would require a hierarchized society, with different people fulfilling different roles or purposes, for it to be applied in a meaningful way, but this is not possible in the U.S. where (unlike in Canada) everybody must be treated equally by definition.

What is the effect of treating everybody in this way (i.e. the same)? It paves the way for the coming to be of the "universal and homogeneous state," ${ }^{\text {"75 }}$ the state in which We Are the World. That this is precisely what The Golden Rule does is confirmed in an interesting way by the circumstances of its production:

One point about the Golden Rule that particularly pleases Norman is that the models appearing in it, though they represent a cross-section of the nations of the world, all came from his home area ... [either from] Stockbridge or from Arlington, Vermont, not far away ... 'Guess it proves that America really is a melting pot,' he noted. ${ }^{76}$

In Colville's paintings, knowledge is not distributed evenly: hand-held mirrors, binoculars, and so on, deflect (as well as extend) his subjects' gazes in different directions, and may be taken to suggest that knowledge is both heterogeneous and tied to position. L. Strauss, On Tyranny (Ithaca: Cornell University Press, 1963) would attribute this to the "tyranny of unwisdom" in the modern democratic State, as would George Grant.

73. Buechner, supra, note 4 at 87.

74. Grant, supra, note 2 at 87 . See further A. MacIntyre, Whose Justice? Which Rationality? (Notre Dame: Notre Dame University Press, 1988) at 106-107.

75. Strauss, supra, note 72.

76. D. Walton, A Rockwell Portrait (Kansas City: Sheed Andrews and MacMeel, 1978) at 220. 


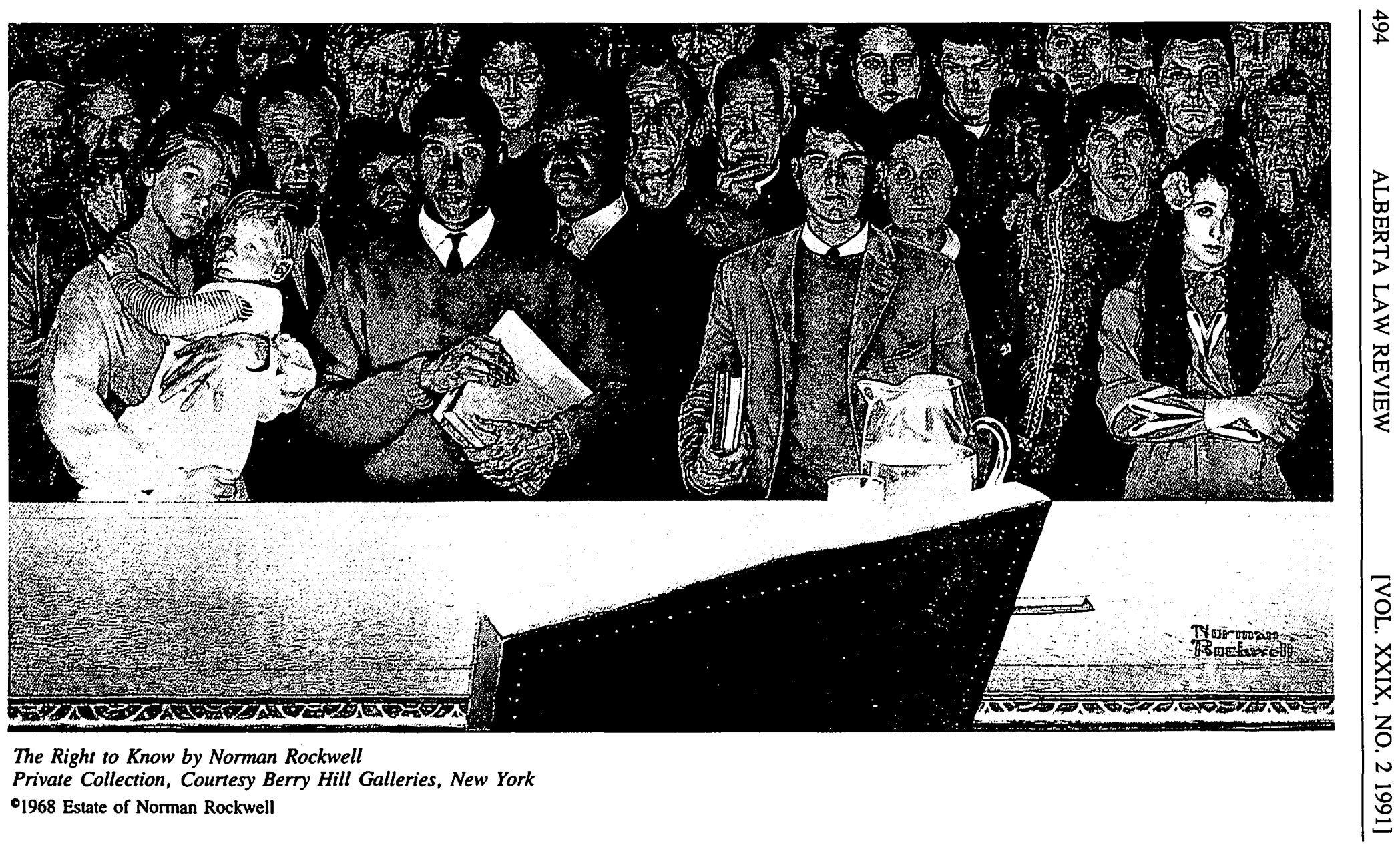


The Golden Rule sets forth a powerful, synthetic vision of man's telos. It will be appreciated how that vision differs from the diathetic vision of a Colville: there is no space within The Golden Rule for any concerted otherness to emerge, even though the painting teems with individuals.

What is life like once the "universal and homogeneous state" has come to be? Rockwell gave us a glimpse of that state in Apollo 11 Space Team. The setting is Cape Canaveral, and all of the figures in this painting - astronauts and pilots, scientists and ground crew, cooks and secretaries - are lined up in rows, their faces turned in the same direction, illuminated by the blast of a rocket. This painting bodies forth the essence of what Arthur Kroker calls "technological liberalism" i.e. the universal technological mastery of nature - but also of man (hence the regimentation, the rows). ${ }^{77}$ It is appropriate to recollect the "dark horse" and "armoured train" of Colville's Horse and Train at this juncture. In Colville's terms, all of the people in Apollo 11 would be inside the train, the technological dynamo of modernity. The "dark horse" has been effaced. In Rockwell's terms, by contrast, Apollo 11 represents the fulfilment of the American Dream: it is the snapshot of history.

One thing about the preceding analysis that might have troubled the reader (though there were probably many things) is the disappearance of American individualism over the course of the last few paragraphs. This is especially troubling in view of my earlier remarks to the effect that individualism has been developed to a greater extent in the U.S. than in Canada. To put the question bluntly: "What ever happened to individualism in the universal and homogeneous state?" The trick, I think, is to recognize that the "individualist" and "melting pot" traditions within the U.S. are not at odds with each other in the same way the "two philosophies, two contradictory views of the fundamental nature of man" are at odds with each other in Canada. The "individualist" and "melting pot" traditions are different sides of the same coin, the "two founding peoples" are struck from different metal.

To recall our earlier discussion, the individual is opposed to and protected from the state under the U.S. Constitution, but the individual is also encompassed by the state (itself considered as an individual), as in that mystic phrase of Whitman's: "I contain multitudes." But there can be no question of encompassment in Canada, because it is not the individual and the state, but the two linguistic and cultural groups, and the two levels of government (federal and provincial), that are opposed to and protected from each other. For the English to absorb the French, or for Ottawa to pass legislation infringing on provincial heads of power, would be unconstitutional. ${ }^{78}$ This is why the state does not figure as an individual, only a kind of "dividual" (a divided whole) in the Canadian consciousness.

77. A. Kroker, Technology and the Canadian Mind: Innis/McLuhan/Grant (Montreal: New World Perspectives, 1984) at 39.

78. It is important to remember that we are discussing tendencies here. It is no more constitutional for Washington to absorb state powers, but that has been the historical tendency. See supra, note 17. 
Recall the paintings Couple on Beach, June Noon and January. Remember the mood of double solitude we detected there. ${ }^{79}$ The theme of solitude also finds expression in American painting, not so much in Rockwell's work, but certainly in Andrew Wyeth's April Wind or Christina's World. But there the solitude is singular rather than double, and that is the key. ${ }^{80}$ The American soul achieves "inward harmony" (Grant) or "psychic integration" (Bateson) so long as it is "at one" either with itself, as in April Wind, or with others, as in The Golden Rule. The Canadian soul is never at one with itself: its "integration" is contingent upon being juxtaposed to some double, as in Lessing's image of the Canadian scriptwriter who watches himself playing a role, or in Colville's couples. In Canada, the minimal conceptual unit is a pair as opposed to a one. Canadians may not be the only people in the world to seek out solitude in pairs, but they are one of the few.

\section{CONCLUSION}

In this essay, we have examined the work of the two most representative artists of the United States and Canada - Norman Rockwell and Alex Colville. We have seen how the separation of figures in Colville's paintings and their fusion in Rockwell's corresponds to the ways in which persons and provinces (or states) are distributed under the Canadian and American constitutions. These contrasting distributions create contrasting species of "grace" or "psychic integration", the striving towards which on the part of both Rockwell and Colville has enabled us to grasp the telos of their respective countries. The destiny of the United States is to actualize the "universal and homogeneous state", while that of Canada remains in the balance. ${ }^{81}$

What are the implications of the present study for proper constitutional studies? If there are laws of cultural production - that is, if the constitution applies as much to the creation of a great painting as to the creation of legislation, and if paintings can be regarded as sources on the constitution, as this essay has attempted to demonstrate, two things follow. First, constitutional law scholars should not confine themselves to the interpretation of legal texts. They should extend their techniques of analysis to the study of works of art. One factor that would weigh in their favour is that instead of producing

See further H. MacLennan, Two Solitudes (Toronto: McClelland and Stewart, 1960).

80. There are also traces of what could be called "plural" or "lonely faces in a crowd" solitude in American painting. One thinks of George Tooker's Subway or Edward Hopper's Nighthawk. There can be no accounting for these representations on my theory. Nor, for that matter, can my theory account for William Kurelek's The Artist and His Family on Toronto's Beach, which is a veritable "celebration of family unity and love ... reflected in the tactility between parents and children and on the smiling faces before us." Tuzi, supra, note 6 at 8 . However, the fact that Kurelek went insane is instructive. See P. Morley, Kurelek: A Biography (Toronto: Macmillan, 1986). It suggests that for a Canadian to paint like Rockwell leads to psychic disintegration. The same may be true of Hopper and Tooker, to the extent they paint like Colville.

81. Or did. The failure of the Meech Lake Accord and the "Mohawk Crisis" of the summer of 1990 suggest that the "juxtapositional philosophy" is no longer understood by our political leaders. All the more reason to stage another Colville retrospective, pack it with politicians, and get them "thinking" again. 
interpretations that are purely whimsical (like Marino Tuzi's critique of Colville's oeuvre), unfounded in fact as well as in law, their interpretations would be legal. Such rigour could only prove beneficial.

Second, constitutional law scholars will have to begin to develop new skills, and in particular skills at "visual thinking" as opposed to strictly "verbal thinking," 82 if they are going to interpret paintings as sources on the constitution with any degree of acumen. In short, they will have to become visionaries in addition to being scribes. This too can only prove beneficial, a source of many new insights. For example, one of the truths about the Canadian constitution we have learned from Colville is the paradoxical fact that "the whole is not greater than its parts, but on a par with them." Such "wisdom" (in Bateson's sense) is only available to the artistic imagination.

Finally, what is traditionally comprehended by the term "constitutional studies" ought perhaps to be extended in the light of the present study to include the study of what Bateson calls the "habits of the heart." Constitutional studies which confine themselves to the analysis of the "mode of organization of a State" are overly restrictive in view of the fact that the term "constitution" also refers to "mental character" and "the character of the body as regards health, strength, etc." (Oxford English Dictionary). In this essay, we have seen how these three levels of meaning (legal, mental and physical) interpenetrate, and cannot really be understood in isolation. 